\title{
SOSIOEKONOMINEN ASEMA JA TYÖKYVYTTÖMYYSELÄKKEELLE SIIRTYMINEN
}

Viime vuosina työkyvyttömyyseläkkeelle siirtyneiden määrä on vähentynyt. Vuonna 2015 omaan työuraan perustuvalle työkyvyttömyyseläkkeelle siirtyi reilut 18000 henkilöä, kun vuonna 2006 heitä oli yli 24000 henkilöä. Samaan aikaan Suomessa väestö ikääntyy. Yhtenä tärkeänä yhteiskunnallisena tavoitteena onkin työurien pidentäminen, mitä osaltaan voidaan edesauttaa työkyvyttömyyseläkkeelle siirtymisen vähentämisellä.

Yleisimmät työkyvyttömyyseläkkeen syyt ovat tuki- ja liikuntaelinten sairaudet ja mielenterveyden häiriöt. Nämä syyt kattavat noin 60 \% kaikista työkyvyttömyyseläkkeelle siirtyneistä. Täysi työkyvyttömyyseläke myönnetään, mikäli henkilön työkyky on alentunut 3/5, ja osittainen työkyvyttömyyseläke, mikäli työkyvyn menetys on vähintään 2/5.

Osatyökyvyttömyyseläkkeen suosio on kasvanut viime vuosina. Erityisesti julkisella sektorilla osatyökyvyttömyyseläkkeet yleistyvät 1990-luvulla. Osatyökyvyttömyyseläkeläisiä on kuitenkin melko vähän verrattuna täyden työkyvyttömyyseläkkeen saajiin.

Yksilöllinen varhaiseläke otettiin käyttöön yksityisellä sektorilla vuonna 1986 ja julkisella sektorilla vuonna 1989. Se oli tarkoitettu ikääntyneille työntekijöille, joiden työkyky oli heikentynyt mutta joiden ei ollut mahdollista päästä tavalliselle työkyvyttömyyseläkkeelle. Yksilölliselle varhaiseläkkeelle pääsyssä annettiin vähemmän painoa lääketieteellisille syille ja siinä painotettiin enemmän työssä jatkamisen mahdollisuutta ja pitkää työuraa. Aluksi yksilölliselle varhaiseläkkeelle oli mahdollista päästä 55-vuotiaana. Myöhemmin ikärajaa korotettiin. Yksilöllinen varhaiseläke lakkautettiin vuonna 2005.

Työikäisen väestön terveydentila on parantunut viime vuosikymmeninä (Palosuo ym. 2007). Tuki- ja liikuntaelinten sairaudet kuten myös verenkiertoelinten sairaudet ovat vähentyneet erityisesti 30-64-vuotiailla. Tästä huolimatta sosioekonomiset terveyserot ovat pysyneet suurina. Alemmissa sosioekonomisissa ryhmissä terveyden on todettu olevan ylempien toimihenkilöiden terveyttä heikompi. Aikaisemmissa tutkimuksissa on myös todettu, että sosioekonomiset erot työkyvyttömyyseläkkeelle siirtymisessä ovat suuret, ja näitä eroja on löydetty erityisesti niillä, jotka ovat siirtyneet työkyvyttömyyseläkkeelle tuki- ja liikuntaelinten sairauksien vuoksi (Leinonen ym. 2011, Ropponen ym. 2011).

Tässä tutkimuksessa selvitetään työkyvyttömyyseläkkeelle siirtymisen sosioekonomisia eroja sairausryhmittäin sekä sosioekonomisia eroja työkyvyttömyyseläkkeelle siirtymisen jälkeisessä kuolleisuudessa. Yhdessä osatutkimuksessa etsitään terveyden, terveyskäyttäytymisen sekä työolojen vaikutusta työkyvyttömyyseläkkeelle siirtymisen sosioekonomisiin eroihin. Sosioekonomisia eroja työkyvyttömyyseläkkeelle siirtymisessä sairausryhmittäin tutkitaan vuodesta 1988 aina vuoteen 2009. Laajat, luotettavat ja riittävän kattavat 
pitkittäisaineistot Suomen väestöstä, eläkkeelle siirtyneistä ja kuolleista, mukaan lukien lukuisat taustatiedot, ovat mahdollistaneet aineiston analysoinnin. Terveys 2000 -aineiston avulla voitiin tutkia työikäisen väestön terveydentilan, terveyskäyttäytymisen sekä työolojen vaikutuksia työkyvyttömyyseläkkeelle siirtymisen sosioekonomiin eroihin.

Terveys 2000 -aineisto sisältää tiedot muun muassa diagnosoiduista somaattisista sairauksista sekä mielenterveyden häiriöistä, jotka jaettiin CIDI-luokituksen mukaan masennukseen, ahdistuneisuushäiriöihin sekä alkoholin käyttöön liittyviin häiriöihin. Tämän lisäksi käytössä oli muun muassa henkilöiden oma arvio terveydentilastaan, sairauspäivärahapäivät sekä terveyskäyttäytymiseen liittyviä muuttujia, kuten alkoholinkäyttö, tupakointi, liikunta ja painoindeksi. Terveys 2000 -aineistolla on myös saatu tietoa työntekijöiden työoloista, kuten työmäärästä, työssä vaadittavista taidoista ja vaatimuksista, sosiaalisesta tuesta, työn fyysisestä raskaudesta sekä muun muassa melun ja pölyn aiheuttamista haitoista. Työkyvyttömyyseläkkeelle siirtyneiden kuolleisuustutkimuksessa käytössä oli 11 prosentin väestöotos Suomen väestöstä vuosilta 1988-2009. Tämän lisäksi aineisto sisälsi 80 prosentin yliotannan kuolleista kyseiseltä ajanjaksolta. Mukana olivat myös kuolinsyytiedot.

1990-luvun alussa työkyvyttömyyseläkkeelle siirtyminen oli varsin yleistä. Työkyvyttömyyseläkkeelle siirtyminen on vähentynyt huomattavasti viimeisten vuosikymmenien aikana kaikissa sosioekonomisissa ryhmissä. Muutokset työkyvyttömyyseläkkeelle siirtymisen yleisyydessä voidaan osittain selittää työmarkkinoiden muutoksella. Varhaisen eläkkeelle siirtymisen on todettu olevan yleisempää taloudellisen kasvun aikoina kuin huonompina aikoina. 1990-luvun alun korkea työkyvyttömyyseläkkeelle siirtyneiden määrä voidaan osaltaan selittää yksilöllisen varhaiseläkkeen korkeana suosiona. 1990-luvulla tapahtunut työkyvyttömyyseläkkeiden alkavuuden väheneminen voidaan sitä vastoin osittain selittää 1990-luvun korkealla työttömyydellä. Tällöin ne, jotka olivat työttömänä, eivät siir- tyneet työkyvyttömyyseläkkeelle. Alkaneiden työkyvyttömyyseläkkeiden lukumäärä väheni erityisesti tuki- ja liikuntaelinten sairauksien takia työkyvyttömyyseläkkeelle siirtyneillä työntekijöillä. Työkyvyttömyyseläkkeiden alkavuuden vähenemistä voidaan myös osittain selittää työikäisen väestön terveydentilan kohentumisella sekä yksilöllisen varhaiseläkkeen ikärajan nousemisella. Myös väestön koulutustaso on muuttunut viime vuosikymmeninä. Pelkän peruskoulutuksen suorittaneiden osuus on vähentynyt samaan aikaan kun ylemmän koulutuksen suorittaneiden osuus on kasvanut. Myös työtehtävät ovat muuttuneet. Teknologian kehitys on muokannut työtehtäviä ja ammatteja. Vaikka kehitys on ollut huimaa, silti monet työtehtävät ovat yhä fyysisesti raskaita.

Tulokset osoittavat, että sosioekonomiset erot työkyvyttömyyseläkkeelle siirtymisessä ovat suuret ja ne vaihtelevat työkyvyttömyyden syyn mukaan. Työntekijöillä on ylempiä toimihenkilöitä suurempi riski siirtyä työkyvyttömyyseläkkeelle. Sosioekonomiset erot työkyvyttömyyseläkkeelle siirtymisessä olivat suurimmat niillä, jotka olivat siirtyneet työkyvyttömyyseläkkeelle tuki- ja liikuntaelinten sairauksien, mielenterveysperusteisten alkoholisairauksien tai verenkiertoelinten sairauksien vuoksi. Esimerkiksi työntekijöiden riski siirtyä työkyvyttömyyseläkkeelle tuki- ja liikuntaelinten sairauksien vuoksi oli noin viisin- tai kuusinkertainen verrattuna ylempiin toimihenkilöihin. Riski oli myös noin viisinkertainen mielenterveysperusteisten alkoholisairauksien takia työkyvyttömyyseläkkeelle siirtyneillä miehillä ja noin kaksinkertainen naisilla.

Työntekijöiden suurta työkyvyttömyyseläkkeelle siirtymisen riskiä selittävät pitkälti työntekijöiden usein fyysisesti raskaat työolot, ja nämä näkyvät erityisesti niillä, jotka siirtyvät työkyvyttömyyseläkkeelle tuki- ja liikuntaelinten sairauksien vuoksi. Alemmissa sosioekonomisissa ryhmissä työolot ovat usein fyysisesti raskaampia kuin enemmän koulutusta vaativissa työtehtävissä. Verenkiertoelinten sairauksien vuoksi työkyvyttömyyseläkkeelle siirtyneillä työntekijöillä työky- 
vyttömyyseläkkeelle siirtymisen riski oli noin kaksinkertainen verrattuna ylempiin toimihenkilöihin. Sen sijaan masennuksen takia työkyvyttömyyseläkkeelle siirtyneillä ei huomattu suuria sosioekonomisia eroja.

Myös ikäryhmittäisiä eroja löydettiin. Sosioekonomiset erot olivat suuremmat nuoremmissa kuin vanhemmissa ikäryhmissä niillä, jotka olivat siirtyneet työkyvyttömyyseläkkeelle mielenterveyssyiden, tuki- ja liikuntaelinten sairauksien, verenkiertoelinten sairauksien tai hermoston sairauksien vuoksi. 50 -64-vuotiailla työntekijämiehillä ja -naisilla työkyvyttömyyseläkkeelle siirtymisen riski masennuksen takia oli pienempi kuin saman ikäisillä ylemmillä toimihenkilöillä, kun taas 30-54-vuotiailla työntekijämiehillä ja -naisilla riski oli noin puolitoistakertainen. Tukija liikuntaelinsairauksien osuus työkyvyttömyyseläkkeelle siirtymisen sosioekonomisista eroista oli suuri koko tarkastelujaksolla.

Työolojen vaikutus työkyvyttömyyseläkkeelle siirtymisen sosioekonomisiin eroihin on suuri. Sen sijaan terveyteen liittyvien tekijöiden, kuten sairauksien tai mielenterveyden oireiden tai itse arvioidun terveydentilan, vaikutus työkyvyttömyyseläkkeelle siirtymisen sosioekonomisiin eroihin oli pienempi. Myöskään terveyskäyttäytymisellä, tässä mitattuna liikkumisella, tupakoinnilla, alkoholin liikakäytöllä tai liikalihavuudella, ei ollut kovin suurta vaikutusta. Työolojen vaikutus sosioekonomisiin eroihin näkyi erityisesti niillä, jotka siirtyivät työkyvyttömyyseläkkeelle tuki- ja liikuntaelinten sairauksien vuoksi tai jotka olivat 50-62-vuotiaita. Työoloista erityisesti työn fyysisellä raskaudella oli suuri vaikutus sosioekonomisiin eroihin työkyvyttömyyseläkkeelle siirtymisessä.

Työolojen selkeä yhteys työkyvyttömyyseläkkeelle siirtymisen sosioekonomisiin eroihin johtunee osaltaan siitä, että työntekijöillä on usein fyysisesti haastavammat työolot kuin ylemmillä toimihenkilöillä. Työntekijöiden työolot voivat sisältää paljon muun muassa kantamista, nostamista, huonoja työasentoja tai altistuksia pölylle tai kemikaaleille. Myös pitkät altistusajat fyysisesti raskaalle työlle, usein jopa vuosikymmenet, asettavat omat vaatimuksensa työntekijöiden terveydelle ja työkyvylle. Työolojen vaikutus näkyy erityisesti sairastuvuutena tuki- ja liikuntaelinsairauksiin. On myös todettu, että työntekijöillä on ylempiä toimihenkilöitä enemmän terveysongelmia, kuten ylipainoa tai alkoholiongelmia.

Sosioekonomiset erot työkyvyttömyyseläkkeelle siirtymisessä vaihtelivat eri mielenterveyssyiden takia työkyvyttömyyseläkkeelle siirtyneillä. Jotkut mielenterveyssyyt esiintyvät todennäköisemmin alemmissa sosioekonomisissa ryhmissä. Tällaisia syitä ovat muun muassa skitsofrenia ja monet päihteiden aiheuttamat mielenterveyden häiriöt. Näiden syiden takia työntekijöillä oli myös suurempi työkyvyttömyyseläkkeelle siirtymisen riski kuin ylemmillä toimihenkilöillä. Sen sijaan masennuksen takia työkyvyttömyyseläkkeelle siirtyminen oli lähes yhtä yleistä kaikissa sosioekonomisissa ryhmissä. Lisäksi työntekijöillä oli ylempiä toimihenkilöitä suurempi riski joutua mielenterveysperusteisten alkoholisyiden takia työkyvyttömyyseläkkeelle. Tämä johtunee siitä, että liiallinen alkoholin kulutus ja siitä aiheutuvat negatiiviset seuraukset ovat yleisempiä alemmissa sosioekonomisissa ryhmissä. Työntekijöillä on myös ylempiä toimihenkilöitä suurempi riski alkoholiperäisiin kuolemiin.

Myös sosioekonomiset erot työkyvyttömyyseläkkeelle verenkiertoelinten sairauksien takia siirtyneillä olivat suuret koko tarkasteluajanjaksolla, vaikka tähän perustuva työkyvyttömyyseläkkeiden alkavuus vähenikin tutkimusajanjaksolla. Verenkiertoelinten sairauksiin liittyviä sosioekonomisia eroja työkyvyttömyyseläkkeelle siirtymisessä selittänevät osittain samat tekijät kuin näihin liittyviä sairastavuus- ja kuolleisuuseroja. Näitä tekijöitä ovat muun muassa biologiset sekä käyttäytymiseen ja terveyteen liittyvät tekijät, kuten fyysinen aktiivisuus, liikalihavuus ja alkoholin käyttö, ja jopa siviilisääty.

Työkyvyttömyyseläkkeelle siirtyneillä kuolleisuus on suurempaa kuin väestöllä keskimäärin. Aikaisemmissa tutkimuksissa on todettu, että sosioekonomiset erot väestön kuolleisuudessa ovat suuret. Sen sijaan sosioeko- 
nomiset erot työkyvyttömyyseläkkeelle siirtyneiden kuolleisuudessa olivat vähäiset. Masennuksen, sydän- ja verenkiertoelinten sairauksien tai hermoston sairauksien takia työkyvyttömyyseläkkeelle siirtyneillä työntekijöillä todettiin olevan hiukan suurempi kuolleisuuden riski kuin ylemmillä toimihenkilöillä. Kun työkyvyttömyyseläkkeelle siirtyneitä tarkasteltiin kuolinsyittäin, havaittiin, että työkyvyttömyyseläkkeelle siirtyneillä työntekijöillä oli suurempi kuolleisuus verenkiertoelinten sairauksiin kuin ylemmillä toimihenkilöillä. Samoin erityisesti työkyvyttömyyseläkkeelle siirtyneillä työntekijämiehillä oli hiukan suurempi riski kuolla alkoholisairauksiin kuin työkyvyttömyyseläkkeelle siirtyneillä ylemmillä toimihenkilöillä.

Löydetyt sosioekonomiset kuolleisuuserot työkyvyttömyyseläkkeelle siirtyneillä voivat osaltaan selittyä samoilla tekijöillä kuin sosioekonomiset kuolleisuuserot yleensä. Terveyskäyttäytymisellä, kuten alkoholin kulutuksella, saattaa olla huomattavakin vaikutus sosioekonomisiin kuolleisuuseroihin. Niillä, jotka olivat siirtyneet työkyvyttömyyseläkkeelle tuki- ja liikuntaelinten sairauksien takia, sosioekonomisia eroja kuolleisuudessa ei havaittu. Työkyvyttömyyseläkkeelle siirtymisen jälkeen työolot eivät enää vaikuta, mikä voi osaltaan tasoittaa sosioekonomisia eroja työkyvyttömyyseläkkeelle siirtymisen jälkeisessä kuolleisuudessa. Toisaalta työn aiheuttamat pysyvät terveysvaikutukset voivat vielä pitkän aikaa työkyvyttömyyseläkkeelle siirtymisen jälkeen lisätä kuolleisuuden riskiä.

Työkyvyttömyyseläkkeelle siirtyneiden kuolleisuustutkimus antaa viitteitä siihen, että työkyvyttömyyseläkkeelle siirrytään samalla lailla terveysperusteisesti kaikista sosioekonomisista ryhmistä, koska kuolleisuusriski työkyvyttömyyseläkkeelle siirtyneillä on lähes samanlainen kaikissa sosioekonomisissa ryhmissä. Toisaalta tähän voivat vaikuttaa monet tekijät. Tulokset voivat toisaalta viitata myös siihen, että sairaimmat ovat kuolleet ennenaikaisesti eivätkä näin ole koskaan edes päätyneet työkyvyttömyyseläkkeelle.
Kirjoitus on YTM Anu Polvisen väitöstilaisuudessaan esittämä lectio praecursoria. Väitöstutkimus "Socioeconomic status and disability retirement in Finland. Causes, changes over time and mortality" tarkastettiin Helsingin yliopistossa 17.8.2016. Väitöskirja on julkaistu Eläketurvakeskuksen tutkimuksia-sarjassa 05/2016. Tutkimus on luettavissa verkko-osoitteessa:

http://www.etk.fi/wp-content/uploads/Socioeconomic_status_and_disability_retirement_ in_finland.pdf.

\section{Lähteet}

Leinonen T, Pietiläinen 0, Laaksonen M, et al. (2011) Occupational Social Class and Disability Retirement among Municipal Employees - The Contribution of Health Behaviors and Working Conditions. Scand J Work Environ Health, 37, 464-72.

Palosuo H, Koskinen S, Lahelma E (toim.) (2007) Terveyden eriarvoisuus Suomessa. Sosioekonomisten terveyserojen muutokset 1980-2005. Sosiaali- ja terveysministeriön julkaisuja 23, Helsinki.

Ropponen A, Silventoinen K, Svedberg P, et al. (2011) Health-related risk factors for disability pensions due to musculoskeletal diagnoses: A 30-year Finnish twin cohort study. Scand J Public Health, 39, 839-848. 